\title{
Chromium in Environment, Its Toxic Effect from Chromite-Mining and Ferrochrome Industries, and Its Possible Bioremediation
}

\author{
Johan J. Coetzee, 1
}

Neetu Bansal, $1 \square$

Emailneetu.bansal@uqconnect.edu.au

Evans M. N. Chirwa, 1

1 Department of Chemical Engineering, University of

Pretoria, Pretoria, 0002 South Africa

Received: 7 October 2017 / Accepted: 30 June 2018

\section{Abstract}

Chromium has long been recognized as a toxic, mutagenic and carcinogenic metal. It is toxic to microorganism, plants, animals and humans. Chromium exists in environment in two stable forms: $\mathrm{Cr}(\mathrm{VI})$ and $\mathrm{Cr}(\mathrm{III}) . \mathrm{Cr}(\mathrm{III})$ is less toxic and insoluble, while $\mathrm{Cr}(\mathrm{VI})$ is extremely toxic and highly soluble. Chromium is used in many industrial applications, but it poses a threat to local environment. The effluents and solid wastes from the mining, chrome-plating, leather-tanning, and dye-manufacturing industries are high in chromium concentration and identified as a major health hazard because of pollution to the environment. Industrial waste is used in landfilling, which causes the seepage, and the leaching of toxic chromium from soil into water bodies poses a threat to the environment. Ferrochrome industry is one of the biggest contributors of the chromium pollution to the water bodies. South Africa has the world's largest chromium reserve. The waste materials produced by ferrochrome industry are slag, dust and processed water. These wastes have high chromium concentration that can cause pollution to the environment. Inhalation is the major exposure route of the $\mathrm{Cr}(\mathrm{VI})$ toxicity in humans. The 
bioremediation of $\mathrm{Cr}(\mathrm{VI})$ to $\mathrm{Cr}(\mathrm{III})$ in the polluted site is a cost-effective and ecofriendly solution for preventing chromium detoxification. Bioremediation can be in situ or ex situ, and choice of remediation method depends upon the extent of pollution and the nature of the site. This paper summarizes the chromium pollution caused by ferrochrome industries, current remediation method adopted by ferrochrome industries, and the possible new methods for effective bioremediation. This paper focuses mainly on bioremediation techniques to convert the high-toxic form of chromium to less-toxic and mobile form of chromium.

\section{Keywords}

Chromium

Bioremediation

Ferrochrome

Pollution

Environment

Bacteria

\section{Background}

Chromium was discovered in 1797 by the French chemist Louis Vauquelin. Chromium was named after the Greek word, "chroma", due to the different colours observed in the chromium-containing compounds (Guertin et al. 2016; Barnhart 1997). Chromium is the 24th element on the periodic table with the symbol $\mathrm{Cr}$ and is situated between vanadium and manganese. It has an average atomic weight of $52 \mathrm{~g} / \mathrm{mol}$. It is a steely-grey, lustrous, hard metal that takes a high polish and has a high melting point (Owlad et al. 2009). Chromium is a very useful metal, and it is utilized in many industrial applications, such as ferrous and non-ferrous alloy metal fabrication, leather-tanning, chrome-plating, and pigment industries. $90 \%$ of the total chrome production is consumed by metallurgical industry. Chromium is the twenty-first most abundant element in the Earth's crust at about $100 \mathrm{mg} / \mathrm{L}$, with the highest reserves found in South Africa and Kazakhstan (Barnhart 1997). Chromium can exist in six valence states, including $0,2+, 3+, 5+$ and $6+$. Chromium occurs predominantly in the $2+, 3+$ and $6+$ oxidation states, but $\mathrm{Cr}^{2+}$ is unstable and oxidizes to $\mathrm{Cr}^{3+}$; beyond that very little is known about its hydrolysis: (Mohan and Pittman 2006; von Burg and Liu 1993). In its metallic form, it is present in oxidation state 0, in chromite compounds as $\mathrm{Cr}(\mathrm{III})$ and in dichromate salt as $\mathrm{Cr}(\mathrm{VI})$. 


\section{Chromite Mining in South Africa}

The global demand for chromite, $(\mathrm{Fe}, \mathrm{Mg}, \mathrm{Al}) \mathrm{Cr}_{2} \mathrm{O}_{4}$, is driven by the need for ferrochrome to be used in wide applications for manufacturing different materials (Cramer et al. 2004). The chromite mining as well as the overall mining sector in South Africa has historically been a crucial factor in the economic growth and advancement of the country (Hamann 2004). The sector has contributed to the development of an extensive and efficient infrastructure and has led to the establishment of secondary industries (Mutemeri and Petersen 2002). The current exploitable reserves of platinum group metals are concentrated in narrow, but extensive strata known as the Merensky Reef, the Platreef, and the UG2 chromite layer found in the Bushveld Indigenous Complex (Jones 1999). The largest concentration of extractable chromite is found along the Merensky Reef, which stretches from the west of the Pilanesberg southwards through the Bafokeng area and Rustenburg towards Marikana, parallel to the Magaliesberg (Howat 1986; Gzik et al. 2003; Glastonbury et al. 2010).

South Africa (SA) holds $72-80 \%$ of the world's viable chromite ore reserves. U.S. Geological survey showed the South Africa was the biggest chromite mine producer in the year 2016 (Fig. 1) (U.S. Department of the Interior and U.S. Geological Survey, January 2017). It produced 14,000 thousand metric tonnes of chromite. The country is also the world's single largest producer of ferrochrome and supplies a majority amount of the world's stainless steel producers' needs and thus has consolidated the growing market for their product. Based on 2015 statistics, the South African ferrochrome smelting industry produced approximately 3,590,000 metric tonnes of ferrochrome (International Chromium Development Association 2016). Due to the friability of the South African chromite ores, it is common to only recover $10-15 \%$ lumpy ore $(15 \mathrm{~mm}<$ typical size range $<150 \mathrm{~mm}$ ) and $8-12 \%$ chip/pebble ores $(6 \mathrm{~mm}<$ typical size range $<$ $15 \mathrm{~mm}$ ) during the beneficiation process employed after chromite mining, which has the effect that large dump sites are formed (Beukes et al. 2010; Glastonbury et al. 2010). 


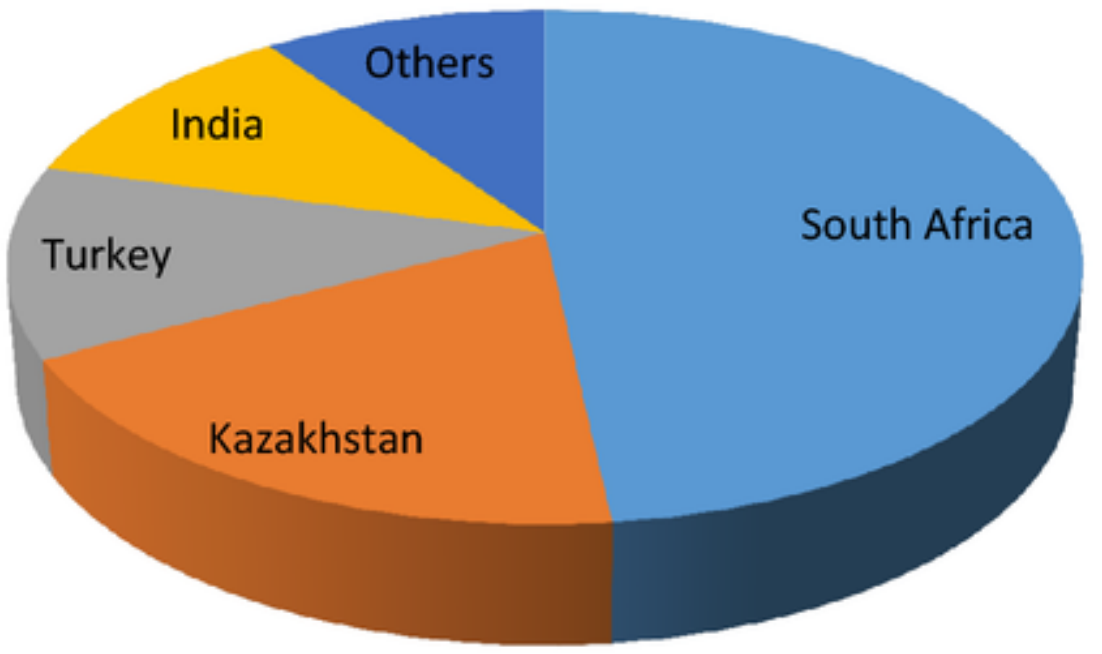

- South Africa $\quad$ Kazakhstan $\square$ Turkey $\square$ India $\quad$ Others

Fig. 1. World chromite production in the year 2016. Reproduced with permission from the U.S. Department of the Interior and U.S. Geological Survey, January (2017)

Chromite-mining and ferrochrome industries not only pollute the land and water, but also contribute significantly to the air pollution. Western Bushveld Complex of the South Africa produces major amount of world's total ferrochromium. Venter et al. (2016) measured chromium in particulate matter of two size groups, $\mathrm{PM}_{2.5}(\leq 2.5 \mu \mathrm{m})$ and $\mathrm{PM}_{2.5-10}(2.5-10 \mu \mathrm{m})$ for one year in regional background site of Bushveld Complex. Their results showed that the chromium of median concentration of $4.6 \mathrm{ng} / \mathrm{m}^{3}$ was detected in air mass that passed over the Bushveld complex mostly in the form of $\mathrm{PM}_{2.5}$; however, chromium in air mass that passed over the regional background was below detection limit of the analytical technique.

\section{Ferrochrome Process and Ferrochrome Waste}

Ferrochromium is an alloy that consists mainly of iron and chromium, containing $45-80 \% \mathrm{Cr}$ and various amounts of iron, carbon and other elements. Ferrochrome is produced through a pyrometallurgical process by barbothermic reduction of chromite ore $\left(\mathrm{FeO} \cdot \mathrm{Cr}_{2} \mathrm{O}_{3}\right)$. Quartzite- and aluminium oxidecontaining materials are used as additives to compensate for high magnesium contents that are found in some ores (Erdem et al. 2005). Chromite ore is considered to be inert and insoluble in water, with chromium mainly occurring in the trivalent state. Mineral chromite is also the most economically extractable chromium-containing ore (Dhal et al. 2013; Sedumedi et al. 2009).

Ferrochrome is manufactured in ferrochrome foundries using electric arc furnaces, which are classified as open, semi-closed or closed. Chromium and 
iron react with carbon, and reduce to form the metal products (Sedumedi et al. 2009; Kumar et al. 2014). The $\mathrm{FeCr}$ alloys produced contain a wide range of $\mathrm{Cr}$ from $50-70 \%$. Ferrochrome with $50-60 \% \mathrm{Cr}$ is called charge chrome, and the one with more than $60 \%$ is called carbon ferrochrome (Sen and Mukherjee 2010; Niemelä and Kauppi 2007). The total chromium that is fed into the process is distributed into three different fractions in the smelter: metal, slag, and dust. The slag is generated during the smelting process and mainly consists of rock constituents; bag filter dust (BFD) generated during the cleaning of off-gas in semi-closed and open furnaces; and venture sludge during the scrubbing of the off-gas from closed furnaces. BFD typically contains the highest concentration of $\mathrm{Cr}(\mathrm{VI})$, while the slag forms the largest amount created by volume (van Staden et al. 2014; Sen and Mukherjee 2010; Loock et al. 2014).

The ferrochrome slag consists mainly of silica, alumina and magnesia, in different phases such as spinel, $\left(\mathrm{MgO} \cdot \mathrm{Al}_{2} \mathrm{O}\right)$, and fosterite, $\left(\mathrm{MgO} \cdot \mathrm{SiO}_{2}\right)$, but also of smaller amounts of $\mathrm{CaO}$, chromium and iron oxides, and metal fragments. The chromium content in slag is $2-12 \%$, present in oxide and metallic forms. Huge quantities of ferrochrome wastes generated are discarded in dumps (Erdem et al. 2005; Panda et al. 2013). Ferrochrome smelter dust, especially from the semi-closed and open furnaces, has been shown to contain significantly higher levels of $\mathrm{Cr}(\mathrm{VI})$ than the maximum acceptable risk concentration that is allowed for waste disposal in South-Africa (Sedumedi et al. 2009). The dust typically contains high levels of $\mathrm{Cr}, \mathrm{Si}, \mathrm{Fe}, \mathrm{Al}, \mathrm{Mg}$ and $\mathrm{C}$. The leachable $\mathrm{Cr}(\mathrm{VI})$ concentrations in both stainless steel and ferrochrome fine dusts are reported to exceed the regulation limits of $0.05 \mathrm{mg} / \mathrm{L}$ for $\mathrm{Cr}(\mathrm{VI})$ in drinking water and $2 \mathrm{mg} / \mathrm{L}$ total limit in South Africa (Ma and Garbers-Craig 2006). Natural leaching and environmental exposure to these ferrochrome waste products often result in the formation and remobilization of $\mathrm{Cr}(\mathrm{VI})$ in the environment, which becomes a serious concern for groundwater pollution and soil contamination (Dhal et al. 2013; Satarupa and Paul 2013).

\section{Chromium in the Environment}

\section{Geology of Chromium}

82 minerals are reported in environment in which 23 are $\mathrm{Cr}(\mathrm{VI})$-containing mineral. However main chromium mineral is chromite, $(\mathrm{Fe}, \mathrm{Mg}, \mathrm{Al}) \mathrm{Cr}_{2} \mathrm{O}_{4}$ that contains $45-80 \%$ chromium as $\mathrm{Cr}(\mathrm{III})$ and $\mathrm{Cr}(\mathrm{VI})$. Although natural presence of $\mathrm{Cr}(\mathrm{VI})$ in the nature is not prominent but association of birnessite (oxide mineral of manganese) with chromite oxidize $\mathrm{Cr}(\mathrm{III})-\mathrm{Cr}(\mathrm{VI})$. Chromite deposits exists as stratiform mafic - ultra mafic chromite deposits (as South Africa's Bushveld deposits) or podiform (deposits in Zimbabwe) or alpine type chromite 
deposits (Motzer and Engineers 2004). Chromite ore is formed by the intrusion and solidification of molten lava and only found in rocks. The average concentration of chromium in rocks is $400 \mathrm{ppm}$. Table 1 shows the rage of chromium found in various sources in various geological region (Motzer and Engineers 2004).

\section{Table 1}

Total chromium in various natural sources

\begin{tabular}{|l|l|l|l|l|}
\hline Source & Units & Average & $\begin{array}{l}\text { Range of Cr } \\
\text { concentration } \\
\text { or total Cr }\end{array}$ & References \\
\hline Rocks & $\mathrm{mg} / \mathrm{kg}$ & 100 & $20-2000$ & Daly et al. (1966) \\
\hline Soil & $\mathrm{mg} / \mathrm{kg}$ & $\begin{array}{l}200 \\
\text { (worldwide) }\end{array}$ & $\begin{array}{l}5.4-710 \\
\text { (Scottish soil) }\end{array}$ & $\begin{array}{l}\text { Berrow and Reaves } \\
\text { Engineers (2004) }\end{array}$ \\
\hline Ground water & $\mu \mathrm{g} / \mathrm{L}$ & 0.2 & $0.02-6$ & Allard (1995) \\
\hline $\begin{array}{l}\text { Rain water } \\
\text { (US) }\end{array}$ & $\mathrm{nM}$ & & 4.6 & Kieber et al. (2002) \\
\hline $\begin{array}{l}\text { Sea water } \\
\text { (Argentine } \\
\text { Basin) }\end{array}$ & $\mathrm{nM}$ & & $5.8-6.6$ & Bonnand et al. (2013) \\
\hline Fresh water & $\mu \mathrm{g} / \mathrm{L}$ & & $1-10$ & $\begin{array}{l}\text { Cundeva and Stafilov } \\
(1995)\end{array}$ \\
\hline Coal (US) & $\mathrm{ppm}$ & 15 & NA-250 & Finkelman (1993) \\
\hline $\begin{array}{l}\text { Crude oil } \\
\text { (Austria) }\end{array}$ & $\mathrm{ppm}$ & $\mathrm{NA}$ & $30-70$ & Manning and Gize (1993) \\
\hline Air (US) & $\mathrm{ng} / \mathrm{m}^{3}$ & $>300$ & - & $\begin{array}{l}\text { Motzer and Engineers } \\
\text { (2004) }\end{array}$ \\
\hline
\end{tabular}

\section{Natural Sources}

Natural sources of chromium in aquatic systems originate from the natural weathering of rock formations, atmospheric fall-out as well as run-off from surface soil systems (Kotaś and Stasicka 2000). Ultramafic rocks naturally contain high concentrations of chromium. Chromium in the trivalent and hexavalent forms are important in the Eh-pH range of natural aquatic systems. Chromium in the hexavalent form is found to be toxic to plants and animals, and has been found to be a strong oxidizing agent, corrosive and a possible carcinogen (Richard and Bourg 1991; Fruchter 2002).

\section{Pollution and Discharge Sources}


$\mathrm{Cr}(\mathrm{VI})$ may occur naturally in the environment, but anthropogenic activities are the main source of chromium pollution (Fig. 2). Anthropogenic sources of chromium-containing waste typically originate from the effluent discharge of industries such as chromium ore refining, production of steel and alloys, metal plating, tanning, wood preservation and pigmentation. These anthropogenic sources contribute about 75,000 tonnes of chromium of which approximately $33 \%$ as toxic $\mathrm{Cr}(\mathrm{VI})$. About 54,000 tonnes of chromium is coming from natural sources (Kieber et al. 2002). Chromium in atmosphere is removed by rain, as studies showed approximately all chromium in atmosphere comes back with rain. The expected residence time in the atmosphere is $<10$ days [Agency for Toxic Substance and Disease Registry (ATSDR) 2015]. Cr(VI) in soils can be leached into surface water due to its high solubility and mobility. $\mathrm{Cr}$ (III) is relatively insoluble in water under common environmental conditions ( $\mathrm{pH}$ 6-9) (Fruchter 2002; Saha et al. 2011; Chai et al. 2009). Natural Cr(III) oxidation to $\mathrm{Cr}(\mathrm{VI})$ happens by catalytic reaction of the Mn-bearing minerals (Fig. 2) Eq. 1. The $t_{1 / 2}$ of this reaction ranging from 0.58 to 37.2 years. Natural $\mathrm{Cr}(\mathrm{VI})$ reduction in the environment typically involves $\mathrm{Fe}(\mathrm{II})$ in solution or $\mathrm{Fe}(\mathrm{II})$ bearing minerals, sulphides and organic matter (Eq. 2) (Loyaux-Lawniczak et al. 2001; Dhal et al. 2013). The rate of reduction of this conversion is much higher with $t_{1 / 2}$ ranging 15 min-53 days (Motzer and Engineers 2004). Most of the chromium in aquatic phase ultimately deposited in sediments, with 4.6-18 years of residence time (Schmidt and Andren 1984).

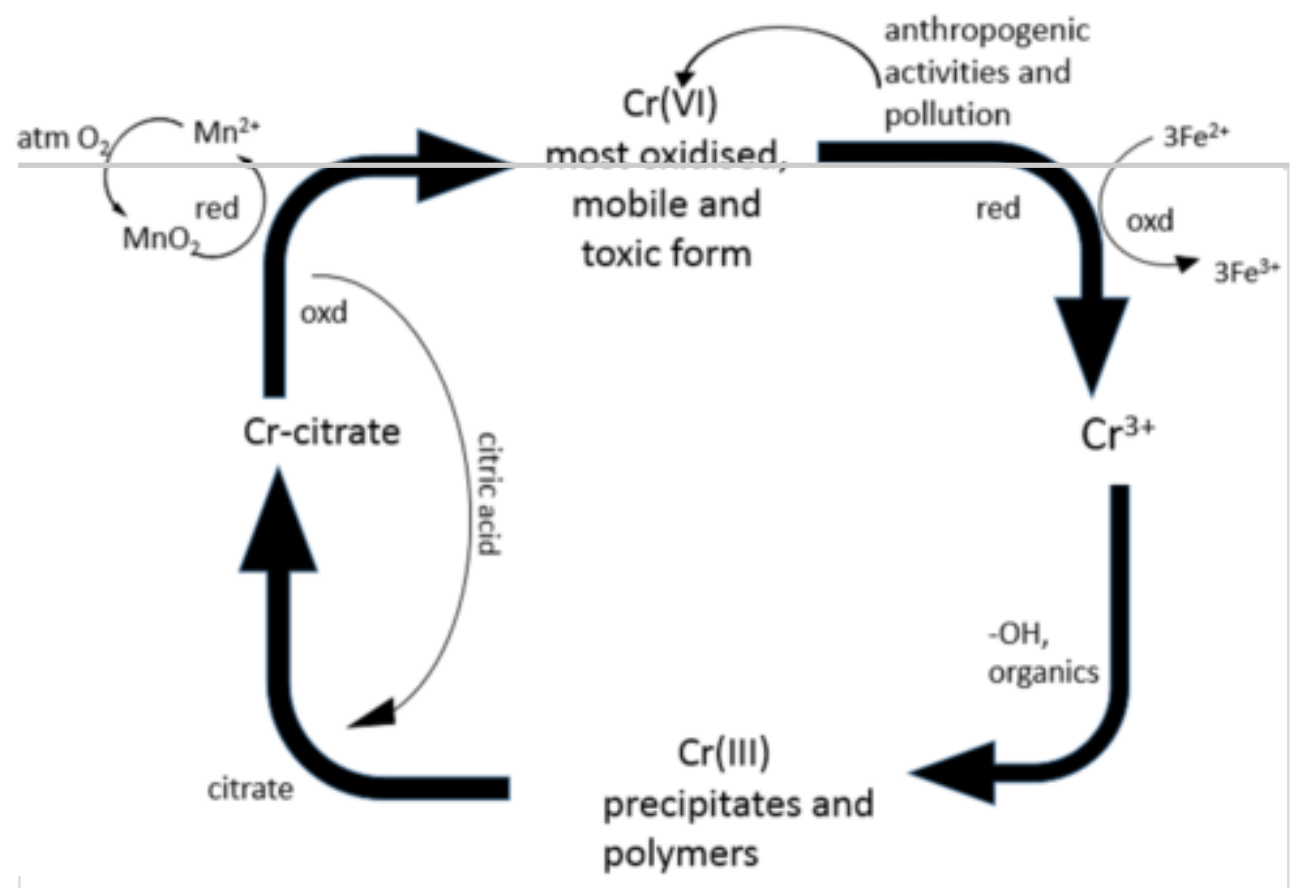

Fig. 2. Natural chromium cycle in the environment Bartlett (1991). 


\section{Speciation of Chromium in the Environment}

The oxidation state of chromium in the environment is determined by the redox potential of the medium. The $\mathrm{pH}$ of the medium affects the complexation of chromium with anions including the hydroxyl ion $\left(\mathrm{OH}^{-}\right)$. Figure 3 shows that the natural occurrence of chromium is in trivalent form. Under standard conditions, the stability zone of trivalent chromium is wide. $\mathrm{Cr}$ (III) compounds occur at wide ranges of $\mathrm{pH}$ and $\mathrm{Eh}$, and both oxidizing and reducing conditions favour the formation of trivalent chromium compounds. This occurs in a $\mathrm{pH}$ range of 514 and with Eh ranging from -0.4 to $0.8 \mathrm{~V}$ (Fig. 3). This correlates with the conditions where a majority of natural biological reactions occur (Molokwane 2010). The stability zone of the $\mathrm{Cr}(\mathrm{VI})$ is much narrower than that of $\mathrm{Cr}(\mathrm{III})$. $\mathrm{Cr}(\mathrm{VI})$ forms $\left(\mathrm{CrO}_{4}{ }^{2-}\right)$ under oxidizing conditions (Fig. 3). 


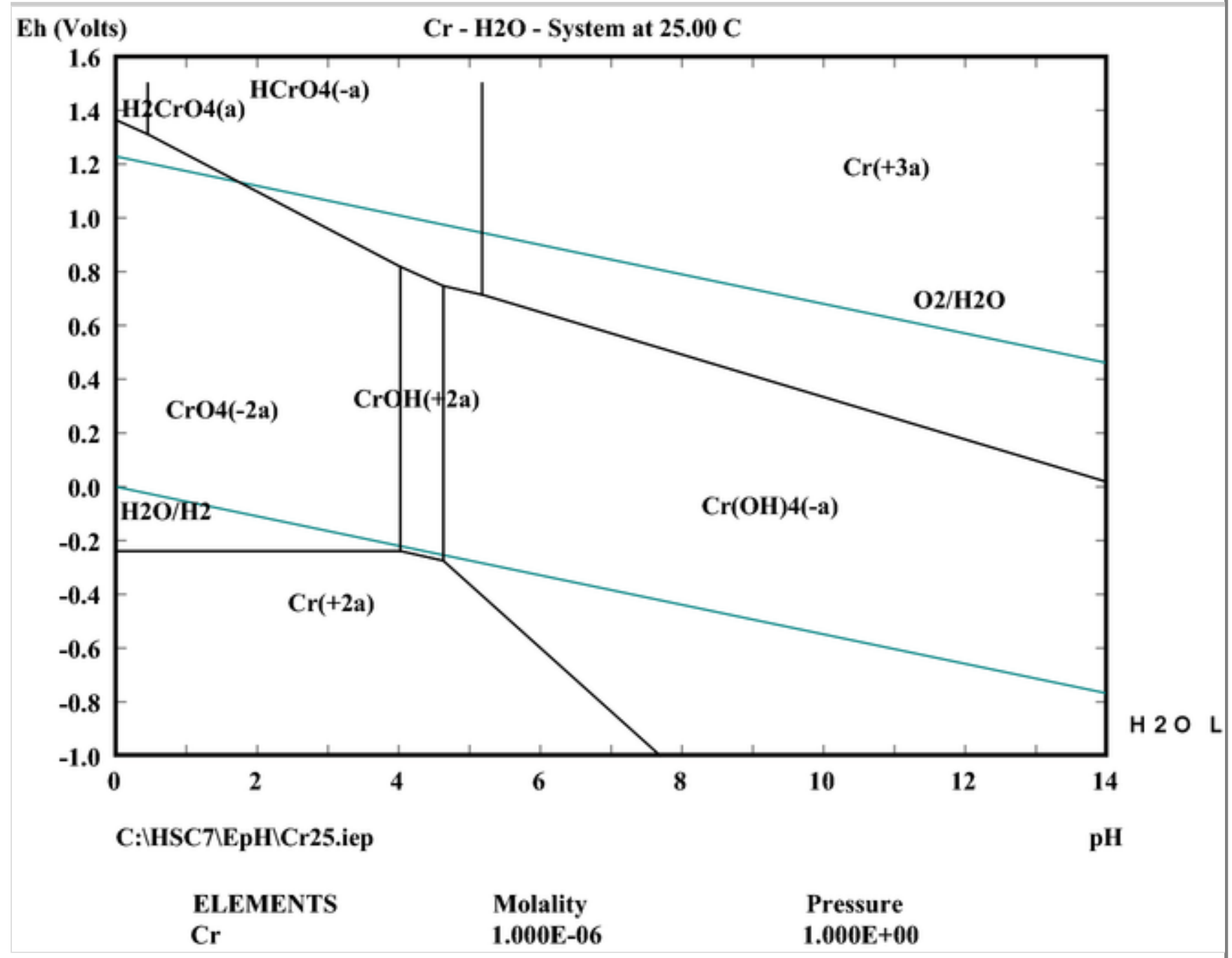

Fig. 3. Eh-pH diagram of chromium. HSC 7.1 Outotec Research Oy Antti Roine (2013)

The $\mathrm{pH}$ and Eh values of the soil/solution decide the valance form of the chromium. High $\mathrm{pH}$ and the presence of the oxidizing agents favour the oxidation of $\mathrm{Cr}$ (III) back to the $\mathrm{Cr}(\mathrm{VI})$. $\mathrm{Cr}$ (III) that is formed during the reduction of $\mathrm{Cr}(\mathrm{VI})$ can re-oxidize again to the $\mathrm{Cr}(\mathrm{VI})$ (Kim and Dixon, 2002). Earlier research has suggested $(<15 \%)$ of the freshly precipitated $\mathrm{Cr}$ (III) was converted to $\mathrm{Cr}(\mathrm{VI})$ in presence of $\mathrm{Mn}$ (III,IV) (hydro)oxide (Hawley et al. 2004). However old precipitate was less susceptible to re-oxidation. The extent of the re-oxidation of $\mathrm{Cr}(\mathrm{III})$ is highly dependent on the $\mathrm{pH}$ of soil and mineralogy of Mn oxides. This oxidation is unlikely in field condition due to the presence of organic matter, sulphides, Fe(II) and other reducing agents, that make the affirmative condition for the Cr(VI) reduction (James et al. 1997).

\section{Chromium in Practice}

The three major industries that use chromium are metallurgical, refractory and chemical. On a worldwide basis about $80 \%$ of the chromium mined goes into metallurgical applications. In the metallurgical industry chromium is used in making steels, alloy cast irons, non-ferrous alloys and miscellaneous other materials (Barnhart 1997; von Burg and Liu 1993). 


\section{Chromium Exposure}

Both Anthropogenic and natural sources are responsible for chromium exposure to humans however, anthropogenic activities are contributing $60-70 \%$ of the total air mission of the chromium [Agency for Toxic Substance and Disease Registry (ATSDR) 2015]. Production of ferrochrome alloy, stainless steel production, tanning industries, chrome plating, chrome pigment production are the major industries where workers are exposed to chromium approximately twice as those among the general population (Pellerin and Booker 2000; Agency for Toxic Substance and Disease Registry (ATSDR) 2015). The common possible routes of exposure to chromium are via ingestion, inhalation and skin contact.

\section{Chromium Exposure by Ingestion}

Food and drinking water containing chromium consumed orally are the major ingestion sources of chromium exposure for humans; however, children exposure comes from ingestion of contaminated soil. One study reported the increased level of chromium $(0.06-156 \mu \mathrm{g} / \mathrm{L})$ in breast milk indicating the exposure via breast milk also [Casey and Hambidge 1984; Agency for Toxic Substance and Disease Registry (ATSDR) 2015]. Fruits, vegetables, fish, and meat contain high chromium concentrations. The typical reported range is $<10$ $1300 \mu \mathrm{g} / \mathrm{kg}$. Some chromium is also added in food through utensils [Agency for Toxic Substance and Disease Registry (ATSDR) 2015]. The drinking water that contains chromium concentration $>25 \mu \mathrm{g} / \mathrm{L}$ contributes considerably towards chromium toxicity. Once $\mathrm{Cr}(\mathrm{VI})$ enters in the body through ingestion, gastric juices convert it to $\mathrm{Cr}$ (III), and only $2-3 \%$ chromium enters in gastrointestinal track (Guertin 2004). There are no enough evidences of carcinogenic nature of chromium if ingested; however, some studies show the increasing cases of gastrointestinal complaints due to chromium (VI) (around $20 \mathrm{mg} / \mathrm{L}$ )contaminated area (Sharma et al. 2012). Cr(VI) compounds cause the ulcers in the stomach and small intestine [Agency for Toxic Substance and Disease Registry (ATSDR) 2015].

\section{Chromium Exposure by Inhalation}

The equilibrium vapour pressure of the chromium is approximately $16 \times 10^{-59}$ $\mathrm{mmHg}$ that makes chromium very non-volatile. The chromium in air is present in the forms of fumes, dust, and, aerosol. WHO calculated the approximate daily intake of chromium via inhalation is $(<0.2-0.6 \mu \mathrm{g})$ [World Health Organization (WHO) 2003]. Inhalation of $\mathrm{Cr}$ (VI) causes the nasal damage, runny nose, asthma, breathing problems and allergies. About $53-85 \%$ of the $\mathrm{Cr}(\mathrm{VI})$ entering 
the lungs is absorbed into the blood or mucous, and the remaining chromium in lungs stays for years and causes the lung cancer (Agency for Toxic Substance and Disease Registry (ATSDR) 2015; Guertin 2004). Chrome-production workers and chromite-plating workers are shown to be more prone to the increased risk of cancer through $\mathrm{Cr}(\mathrm{VI})$ inhalation.

\section{Chromium Exposure by Skin Contact}

Dermal exposure of chromium is not carcinogenic; however, when body comes in contact with chromium-containing products or chromium-containing soil, some amounts of chromium penetrate into the skin. $\mathrm{Cr}(\mathrm{VI})$ penetrates the skin much faster than $\mathrm{Cr}(\mathrm{III})$ due the higher solubility of the former in water. Some $\mathrm{Cr}(\mathrm{VI})$ compounds may burn the skin due to their corrosive nature (Guertin 2004).

\section{Other Chromium Effects on Humans}

Chromium is an essential nutrient for plant and animal metabolism; however, when accumulated at high levels, it can cause serious health problems.

Chromium is very toxic and is considered as a Class A carcinogen by the U.S. EPA (Richard and Bourg 1991; Gibb et al. 2000).

$\mathrm{Cr}(\mathrm{VI})$ is absorbed through cell walls of sulphate-utilizing organisms. Under normal conditions, it spontaneously reacts with the intercellular reductants to generate the short-lived intermediates $\mathrm{Cr}(\mathrm{V})$ and $\mathrm{Cr}(\mathrm{VI})$. The resulting oxidation can release radicals that easily combine with the DNA-protein. $\mathrm{Cr}(\mathrm{VI})$ can also bind to cellular components and deter their normal physiological functions (Cheung and Gu 2007; Dhal et al. 2013).

Acute exposure to $\mathrm{Cr}(\mathrm{VI})$ in humans causes nausea, diarrhoea, liver and kidney damage, dermatitis, internal haemorrhage, and respiratory problems. Inhalation can cause acute toxicity, irritation and ulceration of the nasal septum and respiratory sensitization (asthma) (Mohan and Pittman 2006). Cr(VI) can also accumulate in the placenta, impairing foetal development in mammals (Cheung and $\mathrm{Gu} 2007)$. Exposure levels in excess of $0.1 \mathrm{mg} / \mathrm{g}$ body weight can be lethal (Richard and Bourg 1991). Once Cr(VI) enters the body it changes to $\mathrm{Cr}$ (III) and comes out of the body from urine within a week, but some residual amount stays for years.

Trivalent chromium is an essential trace element in mammalian metabolism. In addition to insulin, it is responsible for reducing blood glucose levels and is used to control certain cases of diabetes. It has also been found to reduce blood cholesterol levels by diminishing the concentration of low-density lipoproteins 
(LDLs) in the blood (Mohan and Pittman 2006). Dietary deficiency of chromium has been associated with impaired growth and fertility, a diabetic hyperinsulinemia, hypercholesterolemia and enhanced atherogenesis (Katz and Salem 1993).

\section{Current Cr(VI) Remediation and Recovery Strategies}

In the ferrochrome industry, high recovery of chromium from waste is desirable due to the savings in raw material and energy. Recovery during the process is typically in the range of 70-93\%, depending on the specific smelting technology applied. Methods used for recovery are usually physical separation methods such as jigging, magnetic separation, dense media separation (DMS), flotation, shaking tables and spirals (van Staden et al. 2014; Holappa and Xiao 2004).

Conventional treatment and remediation techniques of ferrochrome solid wastes include landfilling in approved and controlled landfills, recycling, solidification and stabilization. However, prior to post-treatment processes, the processed and leachate water contaminants need to be reduced to environmentally safe limits. Reducing agents such as $\mathrm{FeCl}_{2}$ or $\mathrm{FeSO}_{4}$ are commonly used. The use of chemical treatment methods are often expensive and can result in secondary environmental problems (Erdem et al. 2005; Gericke 2001; Mulange and Garbers-Craig 2012).

Other uses of ferrochrome slag include usage in cement and concrete production technology as a cementing material or as an aggregate, and also as road-building material, due to the stability and structure of the waste product (Erdem et al. 2005; Wang et al. 2012; Zelić 2005).

Traditionally, $\mathrm{Cr}(\mathrm{VI})$ is removed from water through reduction of $\mathrm{Cr}(\mathrm{VI})$ to $\mathrm{Cr}(\mathrm{III})$ using a reducing agent such as ferrous sulphate, sulphur dioxide or sodium disulphite, followed by precipitation as $\mathrm{Cr}$ (III) or elemental iron (Fiúza et al. 2010). The reduction of $\mathrm{Cr}$ (VI) by dissolved Fe(II) has been reported to be a relatively fast reaction over moderate $\mathrm{pH}$ ranges, taking as little as tens of seconds (Schlautman and Han 2001; Viamajala et al. 2008; Tang et al. 2014). $\mathrm{Cr}(\mathrm{VI})$ in the presence of $\mathrm{Fe}(\mathrm{II})$ is rapidly reduced according to Eq. (3).

The reduction in oxidation-reduction reaction between $\mathrm{Fe}(\mathrm{II})$ and $\mathrm{Cr}(\mathrm{VI})$ occurs on the surface of the iron granules. The size of the iron particles will decrease over time if there is no deposition of products on the surface or if the consumption rate is faster than the deposition rate. This leads to the formation of 
a mixture of $\mathrm{Fe}(\mathrm{III})-\mathrm{Cr}(\mathrm{III})$ particles being released from the iron particle surface (Fiúza et al. 2010).

Iron-reducing bacteria have been found to reduce $\mathrm{Fe}(\mathrm{III})$ to $\mathrm{Fe}(\mathrm{II})$, which was used to reduce $\mathrm{Cr}(\mathrm{VI})$ to $\mathrm{Cr}(\mathrm{III})$, and subsequently re-oxidized $\mathrm{Fe}$ (II) to $\mathrm{Fe}(\mathrm{III})$. This indicates that iron is cycled within the system and behaves as a biocatalyst to constantly transfer electrons to Cr(VI) (Fendorf et al. 2000; Li et al. 2009). This Fe(III) reduction is governed by the bacterium Thiobacillus ferrooxidans (Mesa et al. 2002). Environmental and chemical factors that affect the Fe(III)mediated microbial reduction of $\mathrm{Cr}(\mathrm{VI})$ include the initial $\mathrm{pH}$, temperature, carbon source, $\mathrm{Fe}(\mathrm{II})$ dosage and chelating agent. Initial $\mathrm{pH}$ is the most important factor with bacteria operating well in a range between a $\mathrm{pH}$ of 5-8. Glucose as carbon source was found to be essential for $\mathrm{Cr}(\mathrm{VI})$ reduction and could accelerate the reduction rate (Tang et al. 2014).

\section{Bioremediation of Chromium}

Bioremediation is a technique in which microorganisms reduce/detoxify hazardous pollutant into its less-hazardous form. This transformation process depends upon type of toxins, physical environment and microbial communities. Bioremediation methods are sustainable and do not disturb the natural environment of the polluted site.

Chromium(VI) is toxic to biological systems due to its strong oxidizing potential that can damage cells (Kotaś and Stasicka 2000). Due to chromium toxicity, only few bacterial species that gain chromium tolerance/resistivity can grow in chromium-contaminated soil. Some bacteria have been found to be able to reduce chromium (Polti et al. 2009; Dogan et al. 2011). Romanenko and Koren'kov (1977) isolated first Cr(VI)-reducing species, Pseudomanas sp., from industrial waste water. Since then many researchers isolated many chromiumreducing microorganisms from various sources. Table 2 summarizes a few bacteria that are isolated from chromium-contaminated site, capable of biotransforming high-toxic $\mathrm{Cr}(\mathrm{VI})$ to less-toxic $\mathrm{Cr}(\mathrm{III})$ under aerobic and anaerobic conditions.

Table 2

List of some known $\mathrm{Cr}(\mathrm{VI})$-reducing bacteria in the literature

\begin{tabular}{|l|l|l|l|}
\hline Name of species & $\begin{array}{l}\text { Isolation } \\
\text { conditions/isolation } \\
\text { sources }\end{array}$ & $\begin{array}{l}\text { Growth } \\
\text { medium/carbon } \\
\text { source }\end{array}$ & References \\
\hline $\begin{array}{l}\text { Pseudomonas } \\
\text { mendocina }\end{array}$ & $\begin{array}{l}\text { Aerobic/anaerobic, lab } \\
\text { culture collection }\end{array}$ & $\begin{array}{l}\text { Nutrient Broth }+ \\
\text { galactronic acid } \\
\text { and/or glucuronic } \\
\text { arid }\end{array}$ & $\begin{array}{l}\text { Dogan et } \\
\text { al. (2014) }\end{array}$ \\
\hline
\end{tabular}




\begin{tabular}{|c|c|c|c|}
\hline & & aviu & \\
\hline $\begin{array}{l}\text { Acenetobacter } \\
\text { calcoaciticus }\end{array}$ & $\begin{array}{l}\text { Aerobic/chromite ore } \\
\text { mines }\end{array}$ & Luria-Bertani broth & $\begin{array}{l}\text { Mishra et } \\
\text { al. }(2010)\end{array}$ \\
\hline Bacillus subtilis & $\begin{array}{l}\text { Aerobic/rare-earth ore } \\
\text { mine }\end{array}$ & $\begin{array}{l}\text { Mineral salt media }+ \\
\text { yeast extract }\end{array}$ & $\begin{array}{l}\text { Zheng et al. } \\
(2015)\end{array}$ \\
\hline $\begin{array}{l}\text { Pseudochrobactrum } \\
\text { saccharolyticum } \\
\text { LY10 }\end{array}$ & $\begin{array}{l}\text { Aerobic } \\
\text { Chromium/contaminated } \\
\text { site }\end{array}$ & Luria-Bertani media & $\begin{array}{l}\text { Long et al. } \\
(2013)\end{array}$ \\
\hline $\begin{array}{l}\text { Halomonas sp. TA- } \\
04 \text { (HQ609599) }\end{array}$ & $\begin{array}{l}\text { Aerobic/marine } \\
\text { sediments near a } \\
\text { stainless steel plant }\end{array}$ & $\begin{array}{l}\text { Tryptone }+ \text { yeast } \\
\text { extract }+ \text { D- glucose } \\
+\mathrm{NaCl}\end{array}$ & $\begin{array}{l}\text { Focardi et } \\
\text { al. }(2012)\end{array}$ \\
\hline $\begin{array}{l}\text { Staphylococcus } \\
\text { arlettae strain Cr11 }\end{array}$ & $\begin{array}{l}\text { Aerobic/indigenous } \\
\text { tannery effluent }\end{array}$ & $\begin{array}{l}\text { Tryptone } \\
\text { soyapeptone media }\end{array}$ & $\begin{array}{l}\text { Sagar et al. } \\
(2012)\end{array}$ \\
\hline $\begin{array}{l}\text { Cellulosimicrobium } \\
\text { sp. }(K X 710177)\end{array}$ & $\begin{array}{l}\text { Aerobic/effluent of } \\
\text { tannery industries }\end{array}$ & Luria-Bertani agar & $\begin{array}{l}\text { Bharagava } \\
\text { and Mishra } \\
(2018)\end{array}$ \\
\hline $\begin{array}{l}\text { Bacillus subtilis, } \\
\text { Bacillus safensis, } \\
\text { and Bacillus cereus }\end{array}$ & $\begin{array}{l}\text { Aerobic/wastewater } \\
\text { treatment plant }\end{array}$ & Tryptic soy broth & $\begin{array}{l}\text { Shafique et } \\
\text { al. }(2017)\end{array}$ \\
\hline $\begin{array}{l}\text { Achromobacter } \\
\text { xylosoxidans } \mathrm{SHB} \\
204\end{array}$ & $\begin{array}{l}\text { Aerobic/soil, sludge, } \\
\text { drainage water }\end{array}$ & Nutrient agar & $\begin{array}{l}\text { Rao et al. } \\
(2017)\end{array}$ \\
\hline $\begin{array}{l}\text { Bacillus sp. FY1 and } \\
\text { Arthrobacter sp. } \\
\text { WZ2 }\end{array}$ & $\begin{array}{l}\text { Aerobic/electroplating } \\
\text { and tannery effluent-- } \\
\text { contaminated sites/ }\end{array}$ & $\begin{array}{l}\text { Luria-Bertani (LB) } \\
\text { medium + glucose }\end{array}$ & $\begin{array}{l}\text { Xiao et al. } \\
(2017)\end{array}$ \\
\hline $\begin{array}{l}\text { Pseudomonas } \\
\text { aeruginosa }\end{array}$ & $\begin{array}{l}\text { Aerobic/leather tannery } \\
\text { effluent }\end{array}$ & Nutrient agar & $\begin{array}{l}\text { Munawaroh } \\
\text { et al. } \\
(2017)\end{array}$ \\
\hline $\begin{array}{l}\text { Rhodococcus } \\
\text { erythropolis }\end{array}$ & $\begin{array}{l}\text { Aerobic/coal mine waste } \\
\text { water }\end{array}$ & $\begin{array}{l}\text { Luria-Bertani broth } \\
+ \text { lactate }\end{array}$ & $\begin{array}{l}\text { Banerjee et } \\
\text { al. }(2017)\end{array}$ \\
\hline $\begin{array}{l}\text { Ochrobactrum sp. } \\
\text { strain CSCr-3 }\end{array}$ & $\begin{array}{l}\text { Aerobic/chromium } \\
\text { landfill }\end{array}$ & Glucose & $\begin{array}{l}\text { He et al. } \\
(2009)\end{array}$ \\
\hline
\end{tabular}

\begin{tabular}{|l|l|l|l|}
\hline Name of species & $\begin{array}{l}\text { Isolation } \\
\text { conditions/isolation } \\
\text { sources }\end{array}$ & $\begin{array}{l}\text { Growth } \\
\text { medium/carbon } \\
\text { source }\end{array}$ & References \\
\hline Providencia sp. & $\begin{array}{l}\text { Aerobic- } \\
\text { Anaerobic/contaminated } \\
\text { sites of chemical } \\
\text { industries }\end{array}$ & $\begin{array}{l}\text { Luria broth } \\
\text { (tryptone-yeast } \\
\text { extract }\end{array}$ & $\begin{array}{l}\text { Thacker et } \\
\text { al. (2006) }\end{array}$ \\
\hline $\begin{array}{l}\text { Achromobactersp. } \\
\text { Strain Ch1 }\end{array}$ & $\begin{array}{l}\text { Anaerobic/chromite ore } \\
\text { processing residue } \\
\text { disposal sites }\end{array}$ & $\begin{array}{l}\text { Luria Broth }+ \\
\text { glucose-lactate }\end{array}$ & $\begin{array}{l}\text { Zhu et al. } \\
\text { (2008) }\end{array}$ \\
\hline
\end{tabular}


The bioremediation of hexavalent chromium comprises both an in situ and an ex situ technology (Azubuike et al. 2016). In the in situ techniques, contaminated soil or water is treated on site with the lowest disturbance to the encompassing surroundings. In contrast, in ex situ techniques, contaminants are treated in the alternative controlled environment from the contaminated site by evacuation or pumping out. The in situ technique is more advantageous compared with ex situ technique due to the former's lower cost and lower risk. The in situ biological transformation requires much care as many pollutants show good biotransformation on lab-scale, but limited oxygen supply and limited nutrient availability limit its functionality in the real-life world. The ex situ techniques are pragmatic to the sites where environmental conditions are detrimental to the biological process or because environmental regulation time is too short for in situ remediation (Hemond and Fechner 2015; Kathiravan et al. 2011).

The optimal $\mathrm{pH}$ and temperature for microbial $\mathrm{Cr}(\mathrm{VI})$ reduction are generally associated with the optimal growth conditions of cells. High cell densities are generally required for significant $\mathrm{Cr}(\mathrm{VI})$ reduction to occur (Shen and Wang 1994). Soluble proteins in microbial cells that use NADH as an electron donor generally influence $\mathrm{Cr}(\mathrm{VI})$ by being either an agent required for growth (Viti et al. 2014) or for contributing to enhanced activity (Horitsu et al. 1987) as shown in the following Eq. (4):

The subsurface conditions at the contaminated site may be severely oxygen depleted due to lack of aeration. Under anaerobic conditions, microorganisms reduce $\mathrm{Cr}(\mathrm{VI})$ via mediation of either a soluble reductase, a membrane-bound reductase, or both (Wang 2000; Beller et al. 2013; Cheung and Gu 2007). Some of the anaerobic organisms do not require organic carbon sources as energy sources and electron donors. Some of these utilize $\mathrm{CO}_{2}$ and $\mathrm{HCO}_{3}{ }^{-}$as carbon sources as shown in the following Eq. (5):

The above is an energy-intensive reaction involving the consumption of NADH and ATP where $\mathrm{Cr}(\mathrm{VI})$ is reduced at the expense of cellular growth and maintenance.

Chromium-reducing bacteria acquired the chromium resistance ability, either by reducing $\mathrm{Cr}(\mathrm{VI})$ to $\mathrm{Cr}(\mathrm{III})$ or by emitting $\mathrm{Cr}(\mathrm{VI})$ from the cytoplasm to resist chromium toxicity (Ramírez-Díaz et al. 2008). Bacteria can use the direct or indirect reduction of $\mathrm{Cr}(\mathrm{VI})$ to $\mathrm{Cr}(\mathrm{III})$. The direct enzymatic reduction can be 
achieved by two types of bacteria: dissimilatory metal-reducing bacteria that can use metals as electron acceptors for growth, and the fermentative and other anaerobic metabolic groups (Fruchter 2002). Under aerobic condition, $\mathrm{Cr}$ (VI) reduction to thermodynamically stable $\mathrm{Cr}$ (III) is a multistep process with the formation of intermediate $\mathrm{Cr}^{5+}$ or $\mathrm{Cr}^{4+}$ formation or without the formation of any intermediate. This aerobic reduction mostly uses NADH or NADPH as an electron donor, either to meet its need or to enhance activity (Joutey et al. 2015). Under anaerobic condition, some bacteria use $\mathrm{Cr}(\mathrm{VI})$ as an electron acceptor through the dissimilatory respiratory process (Ramírez-Díaz et al. 2008). The indirect reduction of $\mathrm{Cr}(\mathrm{VI})$ is carried out by sulphur- and iron-reducing bacteria. The sulphate- and iron-reducing bacteria reduce chromium anaerobically through their metabolic end products. This indirect reduction process is faster than chromate-reducing bacteria by many folds. These bacteria can cope with the higher concentration of Cr(VI) (Fude et al. 1994). Many researchers have reported the reduction of $\mathrm{Cr}(\mathrm{VI})-$ to $\mathrm{Cr}(\mathrm{III})$ by sulphate- and iron-reducing bacteria through indirect mechanism via their anaerobic metabolic end products (Arias and Tebo 2003; Qian et al. 2016; Michel et al. 2003; Zhu et al. 2008). Sulphate-reducing bacteria produce sulphide during reduction of sulphate that further reduces $\mathrm{Cr}(\mathrm{VI})$. The iron-reducing bacteria reduce $\mathrm{Cr}(\mathrm{VI})$ with $\mathrm{Fe}(\mathrm{II})$ generated from biological reduction of Fe(III) (Joutey et al. 2015).

Biotransformation of $\mathrm{Cr}(\mathrm{VI})$ has many advantages over chemical and physical methods of $\mathrm{Cr}(\mathrm{VI})$ reduction, as physical and chemical methods are expensive and they themselves produce toxic wastes that need special treatment for disposal. Bioremediation methods are excellent alternative to protect the water bodies from continuous leaching of toxic waste into natural water stream. Bioremediation methods can be used as in situ or ex situ for industrial wasteand chromium-contaminated soil. The chromium removal efficiency of the indigenous bacteria that are already present at the contaminated site can be improved by introducing specific bacterial strains that contain excellent tolerance/reduction capacity. Biostimulator also improves the activity of indigenous bacteria (Dhal et al. 2013).

\section{Bioreactor Techniques}

A bioreactor is a vessel in which various reactions convert specific reactants to the product required under controlled conditions. Bioreactors mimic the environmental conditions of the bacteria to get the maximum growth of the bacteria. The bioreactor technique is an efficient ex situ tool, wherein many parameters such as $\mathrm{pH}$, temperature, oxygen supply, nutrients, substrate and inoculum concentration can be controlled effectively. The bioreactor system can be classified into following categories: 
a. Suspended growth system in this system, contaminated water is circulated in the tank with free-floating microorganisms attached to biological flocs. Sufficient retention time is provided in the tank to get the maximum bioremediation by bacteria. Previous studies have reported the use of suspended growth bioreactor in bioremediation of $\mathrm{Cr}$ (VI) (Tekerlekopoulou et al. 2013; Gopalan and Veeramani 1994; McLean and Beveridge 2001). Suspended culture system is prone to chromium toxicity as a high concentration of chromium leads to loss of biomass (Molokwane 2010). This system is relatively expensive as oxygen diffusion is very low in the wastewater. It is difficult to maintain the oxygen diffusion and mixed liquor flow in the reactor due to high biomass that results in sludge precipitation (Vayenas 2011).

b. Attached growth/biofilm system in this system, cluster of microbial cells in the form of biofilm are attached to inert support matrix such as rock, soil, gravel or plastic material or anything that can provide high surface area. The biofilm that is the extracellular product that can be formed by single microbial species or by the bacterial consortium. Biofilm requires a moist environment and constant supply of nutrient (Singh et al. 2006). Many researchers showed the promising results of $\mathrm{Cr}(\mathrm{VI})$ reduction by biofilm as biofilm showed the high tolerance for the higher concentration of chromium and high hydraulic loading (Nancharaiah et al. 2010; Vayenas, 2011; Tekerlekopoulou et al. 2013; Baldiris et al. 2018).

c. Immobilized cell technique in this technique, bacterial cells or enzymes are fixed to some polymer matrix such as polyacrylamide, polyester, polyurethane, diatomite, agar-agar, agarose and gelatine via chemical or physical methods (Pal et al. 2013; Elangovan et al. 2009). Immobilized cell techniques have many advantages like (1) being cost effective as cells/enzymes are reusable, (2) providing high product yields as it allows for high cell density in small space, (3) protection from shear forces, and (4) providing improved operational stability (Elangovan et al. 2009; Zhu 2007). Several studies have been reported to use immobilized cell and the cell-free enzyme extract of various bacteria for bioremediation of chromium from contaminated water and wastewater (Camargo et al. 2003; Pal et al. 2013; Elangovan et al. 2009; Tekerlekopoulou et al. 2013).

\section{Reduction Pathways}

Many bacteria are capable of reducing $\mathrm{Cr}(\mathrm{VI})$ to $\mathrm{Cr}(\mathrm{III})$ aerobically and anaerobically, through direct microbial reaction, either enzymatically or nonenzymatically (Li et al. 2009). Most of the aerobic reductions are soluble 
enzyme catalysed reactions but Pseudomonas maltophilia O-2 and Bacillus megaterium TKW3 use membrane-associated reductase (Dogan et al. 2011; Cheung and $\mathrm{Gu}$ 2007). In anaerobic $\mathrm{Cr}(\mathrm{VI})$ reaction, $\mathrm{Cr}(\mathrm{VI})$ acts as a terminal electron acceptor, and it can be facilitated by both soluble and membraneassociated enzymes.

\section{Intracellular Processes}

$\mathrm{Cr}(\mathrm{VI})$ is reduced intracellularly to $\mathrm{Cr}(\mathrm{III})$ by various reducing agents like ascorbic acid, sodium sulphite, glutathione, Nicotinamide adenine dinucleotide phosphate hydrogen (NADPH), and Nicotinamide adenine dinucleotide hydrogen (NADH) (Samantaray et al. 2014). Intracellular accumulation occurs when the metal is transported across the cell membrane, which is dependent on microbial activity (Aksu et al. 1991). Soluble reductase enzymes that are able to catalyse reduction of $\mathrm{Cr}(\mathrm{VI})$ to $\mathrm{Cr}(\mathrm{III})$ are produced by bacteria such as $P$. putida PRS200, P. ambigua G-1 and E. coli ATCC33456. Cr(VI) reduction activities are largely dependent on soluble reductase activity as a result of co-metabolism in cells (Shen and Wang 1994).

In intracellular processes, $\mathrm{Cr}(\mathrm{VI})$ is reduced in the cytosol using cytoplasmic soluble reductase enzymes. These enzymes play in intermediate role between associated biological electron donors. The electron donors implicated with $\mathrm{Cr}(\mathrm{VI})$ reduction are NADH and/or NADPH, which are active within a range of temperatures $\left(40-70{ }^{\circ} \mathrm{C}\right)$ and $\mathrm{pH}(6-9)$. According to Suzuki et al. (1992), $\mathrm{NADH}$ in the cell protoplasm donates an electron to $\mathrm{Cr}(\mathrm{VI})$ and generates $\mathrm{Cr}(\mathrm{VI})$ that accepts two electrons from two molecules of the same co-enzyme to produce $\mathrm{Cr}(\mathrm{III})$ Eqs. 6 and 7.

\section{Extracellular Processes}

The removal process of metal species uses adsorption or extracellular polymeric substances and cellular excretions, which clearly shows the involvement of the viable microorganisms. The literature reports show that cell cytoplasm releases the chromium-reducing enzymes into the media, and this has been proven by mass balance of $\mathrm{Cr}(\mathrm{VI})$ and reduced chromium species. This extracellular mechanism is constructive as it does not depend upon transport mechanism, i.e. transfer chromate and dichromate into the cell and export $\mathrm{Cr}(\mathrm{III})$ into the media. 
These reduction mechanisms do not damage cell's DNAs and protect the bacteria from $\mathrm{Cr}(\mathrm{VI})$ toxicity- (Shen and Wang 1994; Molokwane et al. 2008).

\section{Membrane-Bound Processes}

Dead or viable microorganism promotes the membrane-bound process.

Membrane-bound $\mathrm{Cr}(\mathrm{VI})$ reductase has been revealed with P. fluorescens LB300, E. cloacae H01 (Wang et al. 1989; Bopp and Ehrlich 1988), Pseudomonas maltophilia O-2 and Bacillus megaterium TKW3 (Cheung et al. 2006). Mechanism of membrane-bound reductases may ensure the occurrence of $\mathrm{Cr}(\mathrm{VI})$ reduction on the cell surface, forming insoluble $\mathrm{Cr}(\mathrm{OH})_{3}$ in the external medium. As a result, such a reduction mechanism protects cells from $\mathrm{Cr}(\mathrm{VI})$ toxicity.

\section{Conclusion}

This review presents the effect of chromium pollution caused by chromitemining and ferrochrome industries to the environment, its possible toxic effects on human as well as its possible bioremediation methods along with various mechanisms adopted by microbe to reduce high-toxic chromium to its less-toxic form. High concentration of chromium in environment causes a serious threat to the environment. Chromium is classified as class A carcinogen by the U.S. EPA. Conventional methods to treat ferrochrome waste produces secondary toxic wastes which further need disposal. Bioremediation of chromium is an effective technique to mitigate the adverse effects of chromium pollution from soil and water contamination as it utilizes the metabolic process to reduce high-toxic $\mathrm{Cr}(\mathrm{VI})$ to less-toxic $\mathrm{Cr}$ (III) without causing harm to the environment. Many bacteria are capable of reducing toxic form of the chromium(VI) to the nontoxic form of chromium(III) either enzymatically or non-enzymatically.

Bioremediation of the chromium has potential to remove chromium from metalcontaminated sites and waste streams. Bioremediation can either be in situ or ex situ. An appropriate technique can adequately minimize the pollutants' concentration from the polluted site. Bioremediation has significant advantages over conventional method as it is cost effective and is governed by an environmental-friendly technique.

\section{References}

Agency for Toxic Substance and Disease Registry (Atsdr) (2015)

Toxicological profile for chromium. U.S Department of Health ad Human

Services, Public Health Services, ATSDR, Atlanta 
Aksu Z, Kutsal T, Gün S, Haciosmanoglu N, Gholaminejad M (1991) Investigation of biosorption of $\mathrm{Cu}(\mathrm{II}), \mathrm{Ni}(\mathrm{II})$ and $\mathrm{Cr}(\mathrm{VI})$ ions to activated sludge bacteria. Environ Technol 12:915-921

Allard B (1995) Groundwater. In: Aalbu B, Steinnes E (eds) Trace elements in natural waters. CRC Press, Boca Raton

Arias YM, Tebo BM (2003) Cr(VI) Reduction by Sulfidogenic and nonsulfidogenic microbial consortia. Appl Environ Microbiol 69:1847-1853

Azubuike CC, Chikere CB, Okpokwasili GC (2016) Bioremediation techniques-classification based on site of application: principles, advantages, limitations and prospects. World J Microbiol Biotechnol 32:180

Baldiris R, Acosta-Tapia N, Montes A, Hernández J, Vivas-Reyes R (2018) Reduction of hexavalent chromium and detection of chromate reductase (ChrR) in stenotrophomonas maltophilia. Molecules 23:406

Banerjee S, Joshi SR, Mandal T, Halder G (2017) Insight into Cr6 + reduction efficiency of Rhodococcus erythropolis isolated from coalmine waste water. Chemosphere 167:269-281

Barnhart J (1997) Occurrences, uses, and properties of chromium. Regul Toxicol Pharmacol 26:S3-S7

Bartlett RJ (1991) Chromium cycling in soils and water: links, gaps, and methods. Environ Health Perspect 92:17

Beller HR, Han R, Karaoz U, Lim H, Brodie EL (2013) Genomic and physiological characterization of the chromate-reducing, aquifer-derived firmicute pelosinus sp. strain HCF1. Appl Environ Microbiol 79:63-73

Berrow ML, Reaves GA (1986) Total chromium and nickel contents of Scottish soils. Geoderma 37:15-27

Beukes JP, Dawson N, Van Zyl PG (2010) Theoretical and practical aspects of $\mathrm{Cr}(\mathrm{VI})$ in the South African ferrochrome industry. J S Afr Inst Min Metall 110:743

Bharagava RN, Mishra S (2018) Hexavalent chromium reduction potential of Cellulosimicrobium sp. isolated from common effluent treatment plant of tannery industries. Ecotoxicol Environ Saf 147:102-109 
Bonnand P, James RH, Parkinson IJ, Connelly DP, Fairchild IJ (2013) The chromium isotopic composition of seawater and marine carbonates. Earth Planet Sci Lett 382:10-20

Bopp LH, Ehrlich HL (1988) Chromate resistance and reduction in Pseudomonas fluorescens strain LB300. Arch Microbiol 150:426-431

Camargo FAO, Okeke BC, Bento FM, Frankenberger WT (2003) In vitro reduction of hexavalent chromium by a cell-free extract of Bacillus sp. ES 29 stimulated by $\mathrm{Cu}^{2+}$. Appl Microbiol Biotechnol 62:569-573

Casey CE, Hambidge KM (1984) Chromium in human milk from American mothers. Br J Nutr 52:73-77

Chai L, Huang S, Yang Z, Peng B, Huang Y, Chen Y (2009) Cr(VI) remediation by indigenous bacteria in soils contaminated by chromiumcontaining slag. J Hazard Mater 167:516-522

Cheung KH, Gu JD (2007) Mechanism of hexavalent chromium detoxification by microorganisms and bioremediation application potential: a review. Int Biodeterior Biodegrad 59:8-15

Cheung KH, Lai HY, Gu JD (2006) Membrane-associated hexavalent chromium reductase of Bacillus megaterium TKW3 with induced expression. J Microbiol Biotechnol 16:855

Cramer L, Basson J, Nelson L (2004) The impact of platinum production from UG2 ore on ferrochrome production in South Africa. J S Afr Inst Min Metall 104:517-527

Čundeva K, Stafilov T (1995) Determination of total chromium in fresh water by atomic absorption spectrometry following flotation preconcentration. Fresenius' J Anal Chem 352:354-356

Daly R, Manger GE, Clark SP (1966) Section 4: density of rocks. Geol Soc Am Mem 97:19-26

Dhal B, Thatoi HN, Das NN, Pandey BD (2013) Chemical and microbial remediation of hexavalent chromium from contaminated soil and mining/metallurgical solid waste: a review. J Hazard Mater 250-251:272-291 
Dogan NM, Kantar C, Gulcan S, Dodge CJ, Yilmaz BC, Mazmanci MA (2011) Chromium(VI) bioremoval by Pseudomonas Bacteria: role of microbial exudates for natural attenuation and biotreatment of $\mathrm{Cr}(\mathrm{VI})$ contamination. Environ Sci Technol 45:2278-2285

Dogan G, Dogan N, Doganli G (2014) Effect of environmental factors on biological reduction of hexavalent chromium by Pseudomonas mendocina. Asian J Chem 26:7359

Elangovan R, Philip L, Chandraraj K (2009) Hexavalent chromium reduction by free and immobilized cell-free extract of Arthrobacter rhombi-RE. Appl Biochem Biotechnol 160:81

Erdem M, Altundoğan HS, Turan MD, Tümen F (2005) Hexavalent chromium removal by ferrochromium slag. J Hazard Mater 126:176-182

Fendorf S, Wielinga BW, Hansel CM (2000) Chromium transformations in natural environments: the role of biological and abiological processes in chromium(VI) reduction. Int Geol Rev 42:691-701

Finkelman RB (1993) Trace and minor elements in coal. Organic geochemistry. Springer, New York

Fiúza A, Silva A, Carvalho G, De La Fuente AV, Delerue-Matos C (2010) Heterogeneous kinetics of the reduction of chromium (VI) by elemental iron. J Hazard Mater 175:1042-1047

Focardi S, Pepi M, Landi G, Gasperini S, Ruta M, Di Biasio P, Focardi SE (2012) Hexavalent chromium reduction by whole cells and cell free extract of the moderate halophilic bacterial strain Halomonas sp. TA-04. Int Biodeterior Biodegradation 66:63-70

Fruchter J (2002) Peer reviewed: in situ treatment of chromium-contaminated groundwater. Environ Sci Technol 36:464A-472A

Fude L, Harris B, Urrutia MM, Beveridge TJ (1994) Reduction of Cr(VI) by a consortium of sulfate-reducing bacteria (SRB III). Appl Environ Microbiol $60: 1525-1531$

Gericke WA (2001) Bacterial reduction of hexavalent chromium: a viable environmental solution to the treatment of effluent from a ferrochrome smelter pp. 438-443 
Gibb HJ, Lees PS, Pinsky PF, Rooney BC (2000) Clinical findings of irritation among chromium chemical production workers. Am J Ind Med $38: 127-131$

Glastonbury R, Van Der Merwe W, Beukes J, Van Zyl P, Lachmann G, Steenkamp C, Dawson N, Stewart H (2010) Cr(VI) generation during sample preparation of solid samples: a chromite ore case study. Water SA 36:105110

Gopalan R, Veeramani H (1994) Studies on microbial chromate reduction by Pseudomonas Sp. In aerobic continuous suspended growth cultures. Biotechnol Bioeng 43:471-476

Guertin J (2004) Toxicity and health effects of chromium (all oxidation states). Chromium(VI) Handbook. CRC Press, Boca Raton

Guertin J, Jacobs JA, Avakian CP (2016) Chromium(VI) handbook. CRC Press, Boca Raton

Gzik A, Kuehling M, Schneider I, Tschochner B (2003) Heavy metal contamination of soils in a mining area in South Africa and its impact on some biotic systems. J Soils Sediments 3:29-34

Hamann R (2004) Corporate social responsibility, partnerships, and institutional change: the case of mining companies in South Africa. Nat Resour Forum 28:278-290

Hawley EL, Deeb RA, Kavanaugh MC, Jacobs JA (2004) Treatment technologies for chromium(VI). CRC Press, Florida

He Z, Gao F, Sha T, Hu Y, He C (2009) Isolation and characterization of a Cr(VI)-reduction Ochrobactrum sp. strain CSCr-3 from chromium landfill. J Hazard Mater 163:869-873

Hemond HF, Fechner EJ (2015) Chapter 3 - the subsurface environment. chemical fate and transport in the environment, 3rd edn. Academic Press, Boston

Holappa L, Xiao Y (2004) Slags in ferroalloys production-review of present knowledge. J S Afr Inst Min Metall 104:429-437 
Horitsu H, Futo S, Miyazawa Y, Ogai S, Kawai K (1987) Enzymatic reduction of hexavalent chromium by hexavalent chromium tolerant Pseudomonas ambigua G-1. Agric Biol Chem 51:2417-2420

Howat D (1986) Chromium in South Africa. J South Afr Inst Min Metall $86: 37-50$

Hsc 7.1 Outotec Research Oy Antti Roine (2013) Thermodynamical and process calculation software.[Computer software] In:

WWW.OUTOTEC.COM

International Chromium Development Association (2016) Production in 2016. ICDA, Paris

James BR, Petura JC, Vitale RJ, Mussoline GR (1997) Oxidation-reduction chemistry of chromium: relevance to the regulation and remediation of chromate-contaminated soils. Soil Sed Contam 6:569-580

Jones R (1999) Platinum in South Africa to commemorate the 75th anniversary of the discovery of the Merensky Reef. S Afr J Sci 95:525

Joutey NT, Sayel H, Bahafid W, El Ghachtouli N (2015) Mechanisms of hexavalent chromium resistance and removal by microorganisms. In: Whitacre DM (ed) Reviews of environmental contamination and toxicology. Springer International Publishing, Cham

Kathiravan MN, Karthick R, Muthukumar K (2011) Ex situ bioremediation of Cr(VI) contaminated soil by Bacillus sp.: batch and continuous studies. Chem Eng J 169:107-115

Katz SA, Salem H (1993) The toxicology of chromium with respect to its chemical speciation: a review. J Appl Toxicol 13:217-224

Kieber RJ, Willey JD, Zvalaren SD (2002) Chromium speciation in rainwater: temporal variability and atmospheric deposition. Environ Sci Technol $36: 5321-5327$

Kim JG, Dixon JB (2002) Oxidation and fate of chromium in soils. Soil Sci Plant Nutr 48:483-490

Kotaś J, Stasicka Z (2000) Chromium occurrence in the environment and methods of its speciation. Environ Pollut 107:263-283 
Kumar PH, Srivastava A, Kumar V, Majhi MR, Singh VK (2014)

Implementation of industrial waste ferrochrome slag in conventional and low cement castables: effect of microsilica addition. J A Ceramic Soc 2:169-175

Li Y, Low GKC, Scott JA, Amal R (2009) The role of iron in hexavalent chromium reduction by municipal landfill leachate. J Hazard Mater 161:657662

Long D, Tang X, Cai K, Chen G, Chen L, Duan D, Zhu J, Chen Y (2013) $\mathrm{Cr}(\mathrm{VI})$ reduction by a potent novel alkaliphilic halotolerant strain Pseudochrobactrum saccharolyticum LY10. J Hazard Mater 256:24-32

Loock M, Beukes J, Van Zyl P (2014) A survey of Cr(VI) contamination of surface water in the proximity of ferrochromium smelters in South Africa. Water SA 40:709-716

Loyaux-Lawniczak S, Lecomte P, Ehrhardt J-J (2001) Behavior of Hexavalent Chromium in a polluted groundwater: redox processes and immobilization in soils. Environ Sci Technol 35:1350-1357

Ma G, Garbers Craig AM (2006) Cr(VI) containing electric furnace dusts and filter cake from a stainless steel waste treatment plant: part 1Characteristics and microstructure. Ironmaking Steelmaking 33:229-237

Manning DA, Gize AP (1993) The role of organic matter in ore transport processes. Organic Geochemistry. Springer, New York

Mclean J, Beveridge TJ (2001) Chromate reduction by a pseudomonad isolated from a site contaminated with chromated copper arsenate. Appl Environ Microbiol 67:1076-1084

Mesa M, Macias M, Cantero D (2002) Biological iron oxidation by Acidithiobacillus Ferrooxidans an a packed-bed bioreactor. Chem Biochem Eng Q 16:69-74

Michel C, Giudici-Orticoni MT, Baymann F, Bruschi M (2003) Bioremediation of chromate by sulfate-reducing bacteria, Cytochromes $\mathrm{c} 3$ and hydrogenases. Water Air Soil Pollut Focus 3:161-169

Mishra V, Samantaray D, Dash S, Sethi A, Mishra B (2010) Aerobic hexavalent chromium reduction by Acenetobacter calcoaciticus. Biosci Biotechnol Res Asia 7:963-967 
Mohan D, Pittman CU (2006) Activated carbons and low cost adsorbents for remediation of tri- and hexavalent chromium from water. J Hazard Mater $137: 762-811$

Molokwane PE (2010) Simulation of in Situ Bioremediation of Cr(VI) In groundwater aquifer environments using a microbial culture barrier. University of Pretoria, Pretoria

Molokwane PE, Meli KC, Nkhalambayausi-Chirwa EM (2008) Chromium(VI) reduction in activated sludge bacteria exposed to high chromium loading: Brits culture (South Africa). Water Res 42:4538-4548

Motzer WE, Engineers T (2004) Chemistry, geochemistry, and geology of chromium and chromium compounds. Chromium(VI) Handbook. CRC Press, Taylor and Francis, pp 23-88

Mulange Mulange Wa, Garbers-Craig AM (2012) Stabilization of Cr(VI) from fine ferrochrome dust using exfoliated vermiculite. J Hazard Mater 223:46-52

Munawaroh HSH, Gumilar GG, Nandiyanto ABD, Kartikasari S, Kusumawaty D, Hasanah L (2017) Microbial reduction of Cr(VI) into Cr(III) by locally isolated Pseudomonas aeruginosa. IOP Conf Ser 180:012296

Mutemeri N, Petersen FW (2002) Small-scale mining in South Africa: past, present and future. Nat Res Forum 26:286-292

Nancharaiah YV, Dodge C, Venugopalan VP, Narasimhan SV, Francis AJ (2010) Immobilization of $\mathrm{Cr}(\mathrm{VI})$ and its reduction to $\mathrm{Cr}$ (III) phosphate by granular biofilms comprising a mixture of microbes. Appl Environ Microbiol $76: 2433-2438$

Niemelä P, Kauppi M (2007) Production, characteristics and use of ferrochromium slags. Proceedings of the 11th International Ferro Alloys Conference. 171-179

Owlad M, Aroua MK, Daud WAW, Baroutian S (2009) Removal of hexavalent chromium-contaminated water and wastewater: a review. Water Air Soil Pollut 200:59-77

Pal A, Datta S, Paul AK (2013) Hexavalent chromium reduction by immobilized cells of Bacillus sphaericus AND 303. Braz Arch Biol Technol 
Panda CR, Mishra KK, Panda KC, Nayak BD, Nayak BB (2013)

Environmental and technical assessment of ferrochrome slag as concrete aggregate material. Constr Build Mater 49:262-271

Pellerin C, Booker SM (2000) Reflections on hexavalent chromium: health hazards of an industrial heavyweight. Environ Health Perspect 108:A402A407

Polti MA, García RO, Amoroso MJ, Abate CM (2009) Bioremediation of chromium(VI) contaminated soil by Streptomyces sp. MC1. J Basic Microbiol 49:285-292

Qian J, Wei L, Liu R, Jiang F, Hao X, Chen G-H (2016) An exploratory study on the pathways of $\mathrm{Cr}(\mathrm{VI})$ reduction in sulfate-reducing up-flow anaerobic sludge bed (UASB) reactor. Sci Rep 6:23694

Ramírez-Díaz MI, Díaz-Pérez C, Vargas E, Riveros-Rosas H, Campos-García J, Cervantes C (2008) Mechanisms of bacterial resistance to chromium compounds. Biometals 21:321-332

Rao STH, Papathoti NK, Gundeboina R, Mohamed YK, Mudhole G, Bee H (2017) Hexavalent chromium reduction from pollutant samples by Achromobacter xylosoxidans SHB 204 and its Kinetics Study. Indian J Microbiol 57:292-298

Richard FC, Bourg ACM (1991) Aqueous geochemistry of chromium: a review. Water Res 25:807-816

Romanenko V, Koren'kov V (1977) Pure culture of bacteria using chromates and bichromates as hydrogen acceptors during development under anaerobic conditions. Mikrobiologiia 46:414-417

Sagar S, Dwivedi A, Yadav S, Tripathi M, Kaistha SD (2012) Hexavalent chromium reduction and plant growth promotion by Staphylococcus arlettae Strain Cr11. Chemosphere 86:847-852

Saha R, Nandi R, Saha B (2011) Sources and toxicity of hexavalent chromium. J Coord Chem 64:1782-1806 
Samantaray D, Mohapatra S, Mishra BB (2014) 14-Microbial bioremediation of industrial effluents A2Das-Surajit. Microbial biodegradation and bioremediation. Elsevier, Oxford

Satarupa D, Paul AK (2013) Hexavalent chromium reduction by aerobic heterotrophic bacteria indigenous to chromite mine overburden. Braz $\mathrm{J}$ Microbiol 44:307-315

Schlautman MA, Han I (2001) Effects of pH and dissolved oxygen on the reduction of hexavalent chromium by dissolved ferrous iron in poorly buffered aqueous systems. Water Res 35:1534-1546

Schmidt JA, Andren AW (1984) Deposition of airborne metals into the Great Lakes: an evaluation of past and present estimates. Toxic Contam Great Lakes 14:81-103

Sedumedi HN, Mandiwana KL, Ngobeni P, Panichev N (2009) Speciation of $\mathrm{Cr}(\mathrm{VI})$ in environmental samples in the vicinity of the ferrochrome smelter. $\mathrm{J}$ Hazard Mater 172:1686-1689

Sen R, Mukherjee S (2010) Maximisation of chromium content of ferrochrome in DC arc smelting. Min Process Extractive Metall 119:101-106

Shafique M, Jawaid A, Rehman Y (2017) As(V) reduction, As(III) oxidation, and $\mathrm{Cr}(\mathrm{VI})$ reduction by multi-metal-resistant Bacillus subtilis, Bacillus safensis, and Bacillus cereus species isolated from wastewater treatment plant. Geomicrobiol J 34:687-694

Sharma P, Bihari V, Agarwal SK, Verma V, Kesavachandran CN, Pangtey BS, Mathur N, Singh KP, Srivastava M, Goel SK (2012) Groundwater contaminated with hexavalent chromium [Cr(VI)]: a health survey and clinical examination of community inhabitants (Kanpur, India). PLoS ONE 7:e47877

Shen H, Wang Y-T (1994) Modeling hexavalent chromium reduction in Escherichia coli 33456. Biotechnol Bioeng 43:293-300

Singh R, Paul D, Jain RK (2006) Biofilms: implications in bioremediation. Trends Microbiol 14:389-397

Suzuki T, Miyata N, Horitsu H, Kawai K, Takamizawa K, Tai Y, Okazaki M (1992) NAD(P)H-dependent chromium (VI) reductase of Pseudomonas 
ambigua $\mathrm{G}-1$ : a $\mathrm{Cr}(\mathrm{V})$ intermediate is formed during the reduction of $\mathrm{Cr}(\mathrm{VI})$ to $\mathrm{Cr}(\mathrm{III})$. J Bacteriol 174:5340-5345

Tang J, Hu Y, Baig SA, Sheng T, Xu X (2014) Hexavalent chromium reduction by Escherichia coli in the presence of ferric iron. Desal Water Treat $52: 4190-4196$

Tekerlekopoulou AG, Tsiflikiotou M, Akritidou L, Viennas A, Tsiamis G, Pavlou S, Bourtzis K, Vayenas DV (2013) Modelling of biological Cr(VI) removal in draw-fill reactors using microorganisms in suspended and attached growth systems. Water Res 47:623-636

Thacker U, Parikh R, Shouche Y, Madamwar D (2006) Hexavalent chromium reduction by Providencia sp. Process Biochem 41:1332-1337

U.S. Department of the Interior \& U.S. Geological Survey January 2017. Mineral Commodity Summaries 2017. U.S

Van Staden Y, Beukes JP, Van Zyl PG, Du Toit JS, Dawson NF (2014) Characterisation and liberation of chromium from fine ferrochrome waste materials. Miner Eng 56:112-120

Vayenas DV (2011) Attached growth biological systems in the treatment of potable water and wastewater. Comprehensive biotechnology. Elsevier Inc, Amsterdam

Venter AD, Beukes JP, Gideon Van Zyl P, Josipovic M, Jaars K, Vakkari V (2016) Regional atmospheric Cr(VI) pollution from the Bushveld Complex, South Africa. Atmos Pollut Res 7:762-767

Viamajala S, Peyton BM, Gerlach R, Sivaswamy V, Apel WA, Petersen JN (2008) Permeable reactive biobarriers for in situ Cr(VI) reduction: bench scale tests using Cellulomonas sp. strain ES6. Biotechnol Bioeng 101:11501162

Viti C, Marchi E, Decorosi F, Giovannetti L (2014) Molecular mechanisms of $\mathrm{Cr}(\mathrm{VI})$ resistance in bacteria and fungi. FEMS Microbiol Rev 38:633-659

Von Burg R, Liu D (1993) Chromium and hexavalent chromium. J Appl Toxicol 13:225-230 
Wang YT (2000) Microbial reduction of chromate. Environmental microbemetal interactions. American Society of Microbiology, Baltimore

Wang SX, Li N, Wang F, Li B, Li Y (2012) Water-Soluble Cr(VI) of solidification-cured process and compressive strength of Ferrochrome slag complex cement. Appl Mech Mater 144:1096-1099

Wang PC, Mori T, Komori K, Sasatsu M, Toda K, Ohtake H (1989) Isolation and characterization of an Enterobacter cloacae strain that reduces hexavalent chromium under anaerobic conditions. Appl Environ Microbiol 55:1665-1669

World Health Organization (WHO) (2003) Chromium in drinking-water. Background document for development of WHO Guidelines for Drinkingwater Quality, WHO/SDE/WSH/03.04/04

Xiao W, Ye X, Yang X, Zhu Z, Sun C, Zhang Q, Xu P (2017) Isolation and characterization of chromium(VI)-reducing Bacillus sp. FY1 and Arthrobacter sp. WZ2 and their bioremediation potential. Bioremediat $\mathrm{J}$ 21:100-108

Zelić J (2005) Properties of concrete pavements prepared with ferrochromium slag as concrete aggregate. Cem Concr Res 35:2340-2349

Zheng Z, Li Y, Zhang X, Liu P, Ren J, Wu G, Zhang Y, Chen Y, Li X (2015) A Bacillus subtilis strain can reduce hexavalent chromium to trivalent and an nfrA gene is involved. Int Biodeterior Biodegradation 97:90-96

Zhu Y (2007) Chapter 14 - Immobilized cell fermentation for production of chemicals and fuels A2 - Yang, Shang-Tian. Bioprocessing for value-added products from renewable resources. Elsevier, Amsterdam

Zhu W, Chai L, Ma Z, Wang Y, Xiao H, Zhao K (2008) Anaerobic reduction of hexavalent chromium by bacterial cells of Achromobacter sp. Strain Ch1. Microbiol Res 163:616-623 